NASA Technical Memorandum 107511

IECEC-97144

\title{
Thermal Cycling of Mir Cooperative Solar Array (MCSA) Test Panels
}

David J. Hoffman

Lewis Research Center

Cleveland, Ohio

and

David A. Scheiman

NYMA, Inc.

Brook Park, Ohio

Prepared for the

32nd Intersociety Energy Conversion Engineering Conference cosponsored by AIChE, ANS, SAE, AIAA, ASME, and IEEE Honolulu, Hawaii, July 27-August 1, 1997

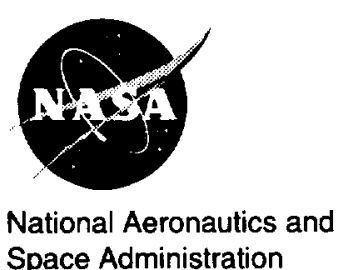

Space Administration 



\title{
THERMAL CYCLING OF MIR COOPERATIVE SOLAR ARRAY (MCSA) TEST PANELS
}

\author{
David J. Hoffman \\ NASA Lewis Research Center \\ 21000 Brookpark Road \\ Cleveland, Ohio 44135 \\ Phone: (216)433-2445 \\ Fax: (216)433-2995 \\ David A. Scheiman \\ Nyma, Inc. \\ 2001 Aerospace Parkway \\ Brookpark, Ohio 44142 \\ Phone: (216)433-6756 \\ Fax: (216)433-6106
}

\section{ABSTRACT}

The Mir Cooperative Solar Array (MCSA) project was a joint US/Russian effort to build a photovoltaic (PV) solar array and deliver it to the Russian space station Mir. The MCSA is currently being used to increase the electrical power on Mir and provide PV array performance data in support of Phase I of the International Space Station (ISS), which will use arrays based on the same solar cells used in the MCSA. The US supplied the photovoltaic power modules (PPMs) and provided technical and programmatic oversight while Russia provided the array support structures and deployment mechanism and built and tested the array. In order to ensure that there would be no problems with the interface between US and Russian hardware, an accelerated thermal life cycle test was performed at NASA Lewis Research Center on two representative samples of the MCSA.

Over an eight-month period (August 1994 - March 1995), two 15-cell MCSA solar array "mini” panel test articles were simultaneously put through 24000 thermal cycles $\left(+80^{\circ} \mathrm{C}\right.$ to $\left.-100^{\circ} \mathrm{C}\right)$, equivalent to four years on-orbit. The test objectives, facility, procedure and results are described in this paper. Post-test inspection and evaluation revealed no significant degradation in the structural integrity of the test articles and no electrical degradation, not including one cell damaged early as an artifact of the test and removed from consideration. The interesting nature of the performance degradation caused by this one cell, which only occurred at elevated temperatures, is discussed.

As a result of this test, changes were made to improve some aspects of the solar cell coupon-to-support frame interface on the flight unit. It was concluded from the results that the integration of the US solar cell modules with the Russian support structure would be able to withstand at least 24000 thermal cycles ( 4 years on-orbit).

\section{BACKGROUND}

The MCSA was brought to Mir by space shuttle Atlantis in November 1995. It remained stowed until May 1996 when it was moved into position on the Kvant module, deployed and a portion of the array was electrically connected. In December 1996, the remainder of the array was electrically connected, enabling the MCSA to provide its full power capability (approximately $6 \mathrm{~kW}$ at the base of the array) to Mir.

The MCSA project was part of Phase I of the ISS program and was managed by an Integrated Product Team involving NASA Lewis Research Center, Rocketdyne (a division of Rockwell International at the time), and Lockheed-Martin in the US and RSC-Energia in Kaliningrad (now Korolev), Russia, near Moscow.

To minimize cost and schedule, the US PPMs were based on the same large-area $(8 \mathrm{~cm} \times 8 \mathrm{~cm})$ silicon solar cell modules used on ISS while the Russian structures and mechanisms were based on existing flight-proven designs. The US PPMs were literally sewn onto the Russian support frames. In order to ensure that there would be no problems with this interface, an accelerated thermal life cycle test was performed at NASA Lewis on two representative samples of the MCSA.

\section{TEST OBJECTIVE}

The objective of this test was to place samples of the MCSA through rapid thermal cycling in order to detect gross design flaws or other weaknesses associated with the integration of the US solar cell modules with the Russian support structure. The primary failure criterion was no detectable power loss over 24000 thermal cycles, equivalent to four years in low earth orbit (the test equipment could detect a degradation in power of about $2 \%$, or slightly less). A secondary subjective criterion was that any structural or mechanical changes resulting from thermal cycling should not be of such a nature or degree which would compromise the MCSA design life. This was considered a development test. 


\section{TEST ARTICLE DESCRIPTION}

There were two MCSA thermal cycling test articles (RUSA-1 and RUSA-2). Each article contained a US-supplied coupon of 15 series-connected photovoltaic solar cells in a 5 cell $\times 3$ cell matrix with one bypass diode in parallel with 10 of the cells. Each of these two coupons were mounted in a Russian-supplied frame assembly. Each test article measured about $457 \mathrm{~mm}$ by $254 \mathrm{~mm}$ (18 inches by 10 inches)

Although not present at the beginning of the tests, two resistance temperature devices (RTDs) identical to the type used for taking temperature measurements of the flight array on-orbit were glued to RUSA- 2 in order to see if they would stay attached and function properly. As with the flight design, five solar cells along one edge have been shortened by $5 \mathrm{~mm}$ so that the coupon would fit into the existing Russian support frame. Both thermal cycle test articles deviated from the flight design, however, in that the shortened edges were pinned to the frame with a metal clip while the flight articles had this edge sewn to the frame with a composite button and nylon thread. This compromise occurred because of the need to rapidly construct the panels during a US visit to RSC-E in Moscow.

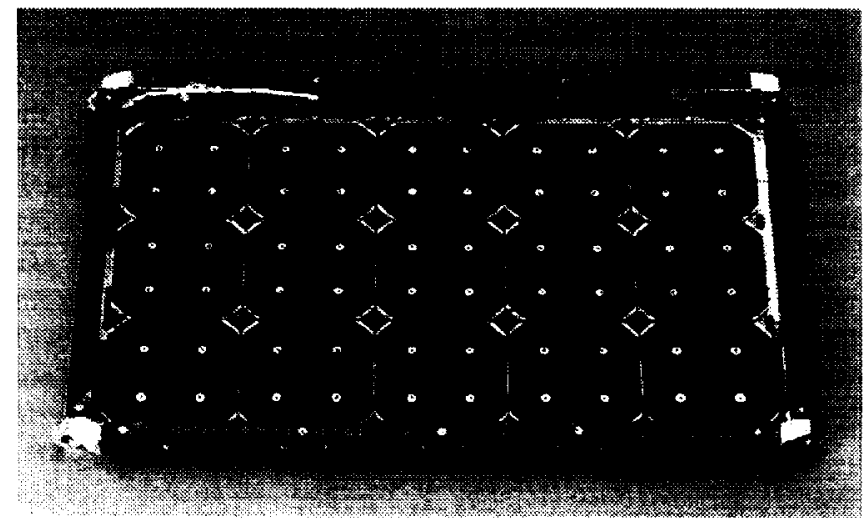

FIGURE 1. TEST ARTICLE FRONT SIDE (RUSA-1)

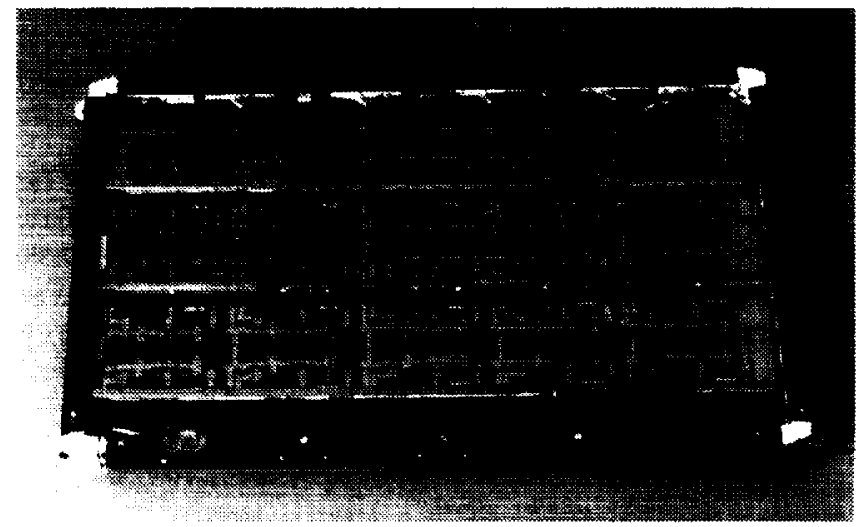

FIGURE 2. TEST ARTICLE BACK SIDE (RUSA-1)
Test article RUSA-2 also included Russian-supplied support rings. The rings were designed to provide additional stiffness to the lightweight, flexible solar cell coupons to ensure that the cells would survive the Space Shuttle vibroacoustic launch environment.

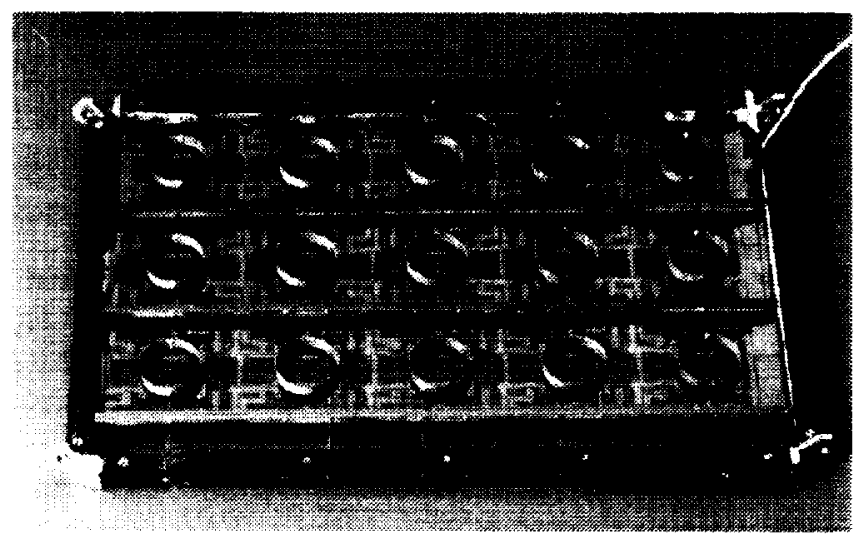

FIGURE 3. TEST ARTICLE BACK SIDE (RUSA-2)

Figure 1 shows the front of one test article while the back of the test article without support rings (RUSA-1) is shown in Figure 2. Figure 3 shows the back side of RUSA-2, giving a view of the support rings. As a result of the development test program, the MCSA team chose to include the support rings in the flight design.

\section{TEST FACILITY}

The thermal cycling test chamber was designed and built at NASA Lewis specifically for rapid thermal cycling of solar array test coupons. The intent was to perform testing as quickly as possible at an affordable cost in order to detect failure modes and gross design flaws due to thermal cycling. Since testing is not performed in a thermal vacuum environment, it is regarded as a development test facility and is not intended to be used for official space qualification.

The thermal cycling test chamber is basically an oven on a freezer (Figure 4). Temperatures can be set to range from $+120^{\circ} \mathrm{C}$ down to $-190^{\circ} \mathrm{C}$ (liquid nitrogen). The oven is heated by two 750 watt convective finned heaters in an outer duct. A low speed fan circulates air downward to minimize any temperature gradient. Two 100 Watt oven bulbs are also present to provide illumination of the coupon for continuity and performance checks during cycling. The freezer is cooled using liquid nitrogen. A fine spray is directed into the chamber and away from the coupons. An exhaust pipe is located near the top of this section to vent excess nitrogen gas. Besides cooling, the nitrogen provides an inert atmosphere for both sections of the chamber. In order to bring the chamber to room ambient temperature quickly ( $<2$ hours), the oven has a nitrogen gas inlet and the freezer has a 500 watt heater. Thermocouples centrally located in each chamber section monitor the temperature. The heating and cooling, either on or off, is computer controlled. The nitrogen flow rates can be manually adjusted. Over temperature shutdown protection is also present. 


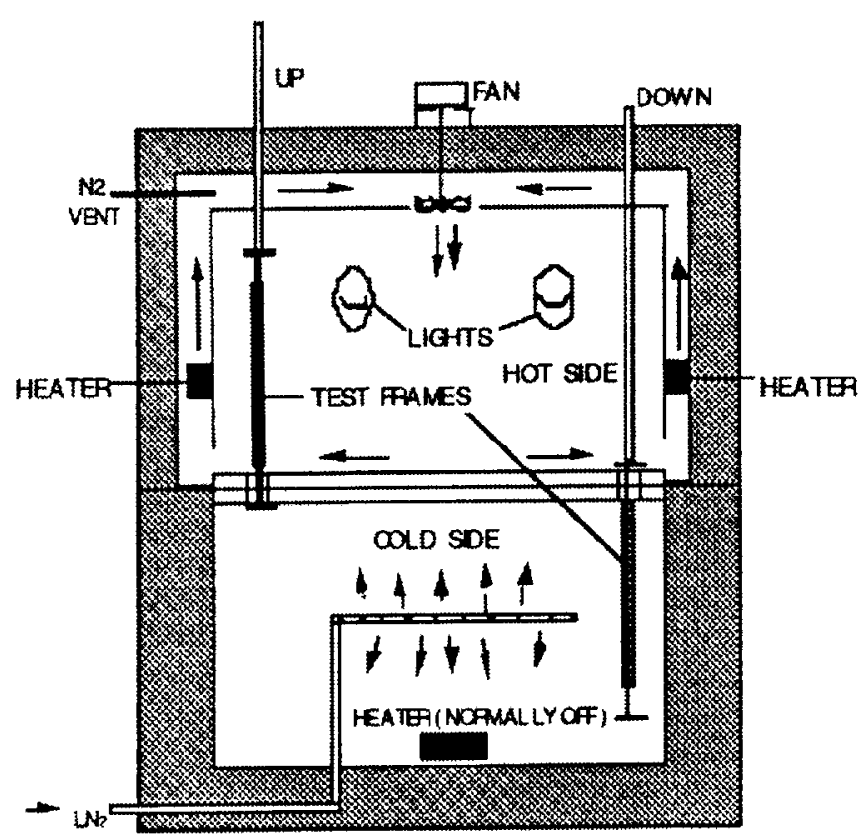

FIGURE4.-THERMAL CYCLE FACILITY

Solar array cell test coupons are mounted on stainless steel frames which fit into a frame holder in the test chamber. An air-driven rod shuttles the frame between the two chambers while a lip on the top and bottom of the frame seals the chamber. Thermocouples mounted on each test coupon control the switching between the hot and cold sections. Once a predetermined number of cycles or a given date is reached, the coupons are left in the chamber's cold section while the chamber shuts down and reaches room temperature.

The test chamber is controlled with IEEE-488 interfaces to a switch controller and a Digital Volt Meter (DVM). The switch controller operates all solenoids for the heaters, liquid nitrogen valves, thermocouple and voltage channels, and frames. The DVM monitors the power supply voltage, cell output (if desired), and reads all thermocouples. Cycle counts are printed out on an hourly basis. Although temperature data can be printed out for $11 / 2$ hour intervals on demand, a complete temperature history is not stored due to limitations in computer memory. The thermocouples are read about every 12-14 seconds. Once operational, the chamber can run seven days a week, 24 hours a day. Chamber operation is controlled by a BASIC computer program which can be modified to accommodate a wide range of requirements, within the overall limits of the equipment.

\section{TEST PROCEDURE}

Both MCSA test articles underwent thermal cycling at the same time. Each was independently cycled between the hot and cold chambers when the temperature exceeded the $+80{ }^{\circ} \mathrm{C}$ and $-100^{\circ} \mathrm{C}$ set points as measured by a thermocouple mounted to back of a cell in the center of each test article. These temperature limits were derived from the temperature extremes calculated for Space Station Freedom solar cells, (now the International Space Station) which are identical to the MCSA solar cells, with $20^{\circ} \mathrm{C}$ development test margins included at both extremes (Scheiman and Smith, 1992). There were no intentional hot or cold temperature soaks. A complete cycle took about 6 minutes on average, leading to 10 cycles per hour. RUSA-2 took slightly longer to cycle due to the higher thermal mass associated with the support rings. Cycle times varied slightly throughout the test because of variations in nitrogen gas leakage and the fluctuation in nitrogen flow rates, among other factors. The test ran automatically with pauses planned at specific intervals when the coupons were removed for electrical performance testing and visual inspection.

\section{Test Measurements}

Electrical performance was measured initially at room temperature with the test articles removed from the chamber: 1) CurrentVoltage (I-V) curves were recorded for the entire 15-cell string using LAPSS 100 Flash Simulator, 2) Dark Diode checks were made on the bypass diodes using a TEK 370A curve tracer.

Visual inspection/mapping was performed under 1-10X magnification. The following list indicates the type of phenomena which could be detected:

- breaks or cracks in the cell surface

- breaks or cracks in the coverglass

- voids or open areas (lack of adhesive)

- wrinkles in the interconnects or blanket

- evidence of adhesive migration or elongation

- any other nonconformity; bubbles, peeling, delamination.

Photographs were taken prior to the test, just after the beginning and then at the end of the test.

\section{Products}

Two I-V curves (as a consistency check) from the flash test were produced at the completion of each major cycle interval from which the following performance parameters were reported: shortcircuit current, current at maximum power, maximum power, efficiency, open-circuit voltage, voltage at maximum power, and fill factor.

For both the front and back sides, a map of flaws found as a result of the visual inspection were updated after the completion of each set of cycles and recorded on a paper image of the test coupon. Brief status reports were written at each major cycle interval.

\section{TEST RESULTS}

After 24000 thermal cycles between $+80^{\circ} \mathrm{C}$ and $-100^{\circ} \mathrm{C}$, no measurable electrical degradation was detected in either test article during room temperature illuminated "flash" tests. Electrical degradation was detected at elevated temperatures in the test article with support rings (RUSA-2), traced to a single cell (\#4). This degradation, which will be discussed in the next section, was most likely the result of a combination of deviations of the test article from the flight design and damage from facility-induced shocks experienced in the early phases of testing, and not as a result 
of thermal cycling. The facility-induced shocks resulted from the air-driven rod which holds the test frame abruptly stopping at the end of a transfer from one chamber to the other. This was mitigated by adjusting the pressure in the pistons and placing springs on the rods to act as stops to dampen the impact of transfer.

There was degradation in some of the structural aspects of both test articles, again most likely due to the test artifacts just mentioned. The pins fastening the shortened cell edges to the frame had tom through the substrate and one support button had fallen off. However, the overall integrity of the solar cell coupon-to-support frame interface was not compromised. Changes were made in the interface to preclude these effects, related to thermal cycling or not, from occurring in the flight unit. The shortened edges were attached more securely with composite buttons instead of the pins and all buttons were further secured by the Russians with thread tied in a double-knot and coated with lacquer. A more detailed account of the events which occurred during the testing and the detailed changes observed in the test articles is described by the authors in a NASA Technical Memorandum (NASA TM-107197, 1996).

\section{ELEVATED TEMPERATURE DEGRADATION}

Up until the accelerated life thermal cycling test reached the one-year equivalent life point of 6000 thermal cycles, room temperature "flash" illumination electrical tests revealed no degradation in the power output of either 15-cell coupon test article. However, since Lockheed-Martin confirmed RSC-Energia's report of degraded electrical power output resulting from damage experienced during an acoustic environment development test of an MCSA PPM test article in Russia only at elevated temperatures (Chau and Brisco, 1995), it was decided to perform elevated temperature electrical performance tests on the thermal cycling test articles. This was done at a count of about 6400 cycles.

\section{Full Coupon Elevated Temperature Tests}

The thermal cycling facility had the capability of obtaining constant illumination electrical performance data (I-V curves) while the test articles were in the hot chamber of the facility. Illumination was provided by two 100 watt incandescent light bulbs. Current-voltage characteristics were obtained with a programmable curve tracer via four-wire measurements. Since the intensity and spectrum of the light provided by the incandescent bulbs were not representative of solar insolation conditions onorbit at air mass zero, the absolute I-V measurements were not in themselves meaningful. However, the relative shape of the I-V curves revealed anomalous behavior.

I-V curves were obtained for both RUSA-1 and RUSA-2 over a wide range of temperatures (approximately $-10^{\circ} \mathrm{C}$ to $+75^{\circ} \mathrm{C}$ ). The I-V curves for RUSA- 1 showed normal characteristics. However, the I-V curves for RUSA-2 showed about a 50\% drop in current for temperatures above $+40^{\circ} \mathrm{C}$. Since these tests were performed while thermal cycling was in progress (the test articles reside for approximately 3 minutes in each chamber, either hot or cold) and an I-V curve trace is more or less instantaneous, it was possible to monitor the I-V curve through most of the temperature range. The $50 \%$ drop in current was rather abrupt and very consistent at the $+40^{\circ} \mathrm{C}$ point.

\section{Failure Isolation: Individual Cell Tests}

At a cycle count of about 7500, RUSA-2 was removed from the test facility in order to isolate the cause of the electrical power degradation. The plan was to heat individual cells above $+40^{\circ} \mathrm{C}$ one at a time, perform a flash illumination electrical test (i.e. "flash test"), and look for the "double-dip" or "stairstep" characteristic in the I-V curve. This was the same process that Lockheed-Martin used to isolate the failure in the development test article (PPM \#2).

First, a room temperature $\left(25^{\circ} \mathrm{C}\right)$ flash test of the entire 15-cell coupon gave a baseline I-V curve. Then each cell was heated to about $+80^{\circ} \mathrm{C}$, as measured by a thermocouple in surface contact with the coverglass in the middle of the cell. This was done with a small, focused hot-air gun. When the thermocouple read near $+80^{\circ} \mathrm{C}$, the heat gun was removed and a flash test of the entire 15-cell coupon was quickly performed. The thermocouple reading at the moment of flash was recorded on the I-V plots. This process was repeated for all 15 cells.

The current-limiting phenomenon was isolated to one of the shortened cells along the top pinned edge of the coupon: the fourth cell from the left (cell \#4). All other cells had normal I-V curves.

Flash tests were performed over a range of temperatures for cell $\# 4$. The onset of degradation began near $+40^{\circ} \mathrm{C}$ with a "softening" of the I-V curve. Softening of the curve continued at $+50^{\circ} \mathrm{C}$ while the current limiting effects began to be seen at $+60^{\circ} \mathrm{C}$ and were most pronounced at $+70^{\circ} \mathrm{C}$.

As for the physical condition of cell \#4, inspection with an unaided eye from a number of different angles revealed at least two fairly large cracks in the coverglass. A portion of one of the cracks appeared also to be in the silicon wafer itself. A detailed visual inspection under magnification revealed many cracks, both in the coverglass and the silicon wafer. Also, this row of cells was no longer under any preload due to the pins attaching the cells to the frame having torn through the substrate.

After the testing described above, RUSA-2 was placed back into the test facility and thermal cycling was resumed. High temperature I-V curves were obtained while the test articles were in the hot chamber prior to removing them from the facility for routine inspections at the 12000,18000 and 24000 cycle points. In addition, individual cell elevated temperature tests were performed on RUSA- 2 for comparison with the baseline obtained at the 7500 cycle point.

At this point, it was decided by the MCSA US team to alter the failure criterion for RUSA-2. Since the damage to cell \#4 was most likely caused by a combination of test article deviations (i.e. the pinned edge tear-through and glue softening) and facility problems not related to thermal cycling, the team decided to monitor the performance of only the bottom two rows of cells (10 total) on RUSA-2 for the remainder of the test. 


\section{Possible Causes}

Since the elevated temperature degradation was believed to have resulted from artifacts of the test not related to thermal cycling effects, only a preliminary explanation of the possible cause was pursued.

Supplemental testing had shown that the observed anomaly appeared to be due to a loss of area in the cell rather than a change in shunt or series resistance alone. The evidence for this will now be discussed.

Electrical output of a solar cell is defined by a current vs. voltage (I-V) curve. The parameters of the curve, all affected by cell quality, are listed as follows:

$I_{s c}=\quad$ Short Circuit Current ( 0 volts); Related to cell area and illumination intensity

$\mathrm{V}_{\mathrm{oc}}=$ Open Circuit Voltage ( 0 amps); Related to cell material (bandgap).

$P_{\max }=$ Maximum Power (Knee of Curve); Related to series and shunt resistances.

$I_{\max }=$ Current at Maximum Power

$\mathrm{V}_{\max }=$ Voltage at Maximum Power

F.F. = Fill Factor; Defines the "squareness" of the curve, 1 is ideal. $\mathrm{P}_{\max } /\left(\mathrm{V}_{\mathrm{oc}} * \mathrm{I}_{\mathrm{sc}}\right)$

Efficiency $=($ Power Out $/$ Power In $)$

A solar cell is equivalent to a large area diode. It has a thin negative $(N)$ top layer, a thick positive $(P)$ bottom layer, capacitance, series resistance, and shunt resistance. The solar cells used in the MCSA have $6 \mathrm{P}$ welds and $4 \mathrm{~N}$ welds and extensive grid lines on both the front and back sides of the cell. Physical damage to a cell could affect its electrical output in different ways, from no effect at all to various degrees:

1) No effect at all: Cracks that break a cell cleanly do not cause any performance loss provided there is an unchanged current path to a front and back contact. The cells used in the MCSA could easily be broken into 4 smaller cells (quadrants) in parallel. The loss in power would be negligible.

2) Increased Series Resistance: Cracks in a cell which prevent proper current flow to the nearest contact (weld) pad tend to increase series resistance. A crack of this type must not only be through the cell but also sever the grid lines. Grid lines are optimized to compromise series resistance and shadowing (blockage). They are also optimized to direct current to a contact pad. Because all the grids are connected, loss of a contact pad (weld) will result in increased current at another contact pad, limiting the power loss from the entire cell.

3) Decreased Shunt Resistance: This is caused by localized shorting in the cell. A crack in a cell causes the $N$ top layer to contact the $P$ bottom layer. In most cases, cracking results in a slight separation of the cell at the crack which would prevent any kind of shunting. Natural shunts occur in the cell fabrication and therefore are apparent at the cell measurement. Poor welding techniques will also cause shunting, excessive heat during welding will tend to cause the contact to burn through the thin $\mathrm{N}$ top layer and short the cell. Large area cells have inherently lower shunt resistance.
4) Loss of Current: Short circuit current is directly proportional to cell area and illumination intensity. A loss in current would be directly related to a loss in area (intensity being constant). Extreme cases of high series resistance and/or shunting will also cause a loss in short circuit current. Micrometeoroid impacts that go cleanly through the cell will result in a loss of current proportional to the loss in area. Shadowing will also cause a loss of current. This is intensity related, a $50 \%$ loss in light will produce $50 \%$ loss in current. Cracking in the cell would have to eliminate any electrical connection to the rest of the cell resulting in a loss of area.

The above information is characteristic of a single cell. An array of cells has additional considerations that also affect its electrical output. Cells connected in series and parallel will have different effects on the overall array output. Connected in series, each cell adds voltage while current is limited to that which is produced by the weakest cell. Connected in parallel, each cell adds current while voltage is limited to the weakest performing cell's voltage. Bypass diodes and blocking diodes are yet another consideration. Bypass diodes sacrifice voltage for current in array strings. The shape of a solar array I-V curve will reveal the nature of any damage.

Changes in series and shunt resistance affect the knee of the I-V curve and can best be shown graphically. Damage resulting in an increase in series resistance changes the I-V curve slope from the maximum power point to the open circuit voltage point. Damage resulting in a decrease in shunt resistance affects the slope from the short circuit current point to the maximum power point. Extreme changes in these resistances will affect both the short circuit current and open circuit voltage.

In order to illustrate these various effects, damage to an array of four MCSA-type solar cells connected in series was simulated. First, one cell was shunted while the other three cells were left untouched. Second, series resistance was added to the 4-cell string to show the effect of losing contact weld pads. Last, half of one cell was covered, or shadowed to simulate a loss of area within the cell. Figure 5 shows the results as compared to a normal 4-cell I-V curve.

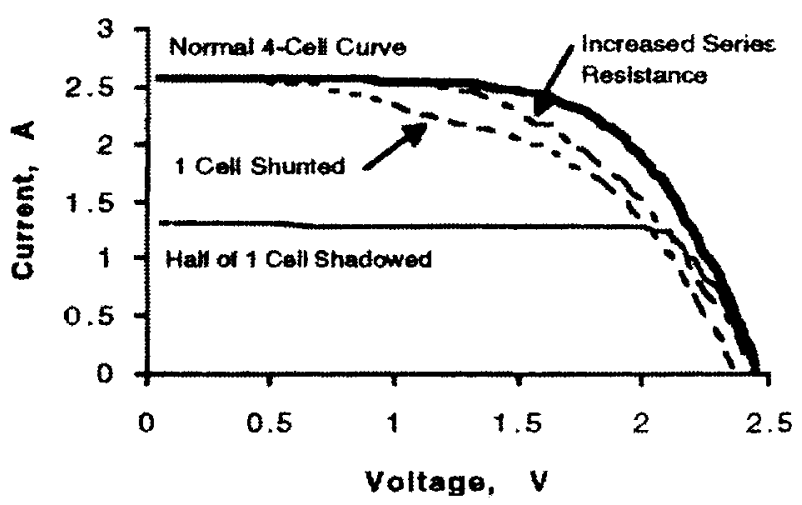

FIGURE 5. DEGRADATION IN 4 SERIESCONNECTED CELLS 
A normal IV curve for the 15-cell series-connected RUSA-2 thermal cycle test article is shown in Figure 6.

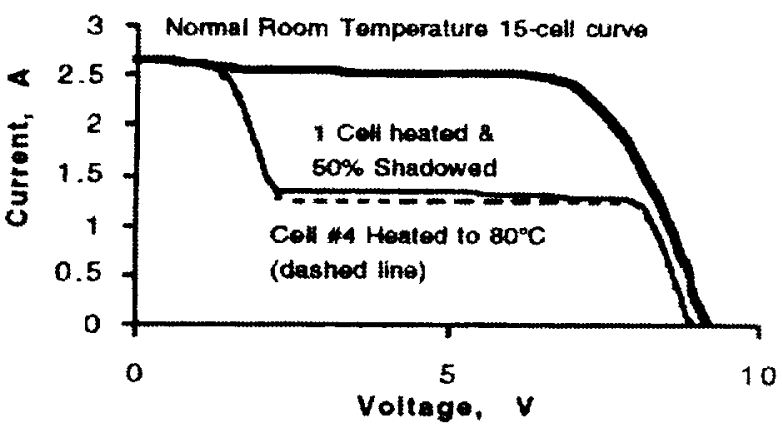

\section{FIGURE 6. DEGRADATION IN 15-CELL TEST ARTICLE (RUSA-2)}

The slight hump in the I-V curve near $\mathrm{I}_{s c}$ is due to the bypass diode. The bypass diode is across 10 cells, which includes 5 cut cells shortened to $7.5 \times 8 \mathrm{~cm}$ instead of the normal full $8 \times 8 \mathrm{~cm}$. The cut cells limit the maximum current through most of the I-V curve. Once the bias voltage drops below the voltage of the final row of cells, the bypass diode operates, eliminating 10 cells form the circuit, and the current is only supplied by the remaining 5 uncut cells and rises up to the full area value.

The dashed line labeled "Cell \#4 Heated to $80^{\circ} \mathrm{C}$ " shows the I-V curve shape which resulted after heating the bad cell (cell 4) in RUSA-2. Notice the current is limited to nearly $50 \%$ of the baseline. This curve is nearly identical to the result obtained after one-half of one cell was covered, or shadowed, so that it only produced half of its full area current capability, labeled " 1 Cell Heated \& 50\% Shadowed". The very obvious similarity in these two I-V curves indicates that a loss of area in cell \#4 is one possible explanation of the current drop seen at elevated temperatures. Note the I-V curve shape reveals no shunting or increased series resistance characteristics, which would seem to rule out explanations using those phenomenon by themselves.

Further evidence that an area loss is the most likely cause can be seen by examining the I-V curves taken while the coupon was in the thermal cycling chamber. While the light intensity of the flash testing is one sun, the intensity of the illumination in the thermal cycling chamber is only one-third sun. However, the I-V curves have the same overall shape at both intensities. The fact that the percentage current reduction and curve shapes are identical for two different intensity levels eliminates series resistance or shunting problems as the sole source of the degradation. Had the cause been related to series resistance, the current loss would have been less at the lower intensity due to lower series voltage losses.

\section{High Temperature Degradation Summary}

The evidence gathered from the experiments described above indicate that the current loss in the RUSA- 2 test coupon appears to be due to a loss in cell area. The underlying cause of the area loss is more difficult to explain. Although cracks are visible on the cells, the areas lost do not visibly appear to be separated from reaching any of the 10 contact pads (they are still contributing to cell performance). As with most cell cracking and fatigue damage, as thermal cycling progresses, the condition should tend to worsen. The effect noted above did not worsen as cycling continued, but remained unchanged.

Finally, an illuminated electrical test while heating the bad cell and shadowing different areas of the cell allowed it to be determined that the upper half was the bad area of the cell.

\section{CONCLUSION}

The appearance of electrical performance degradation only at elevated temperatures reveals the importance of performing illuminated electrical tests over the entire range of operating temperatures for cells which have been exposed to environmental stresses.

In eight months, this test successfully demonstrated the equivalent of four years of low earth orbit thermal cycling, a total of 24000 cycles, on two samples of the Mir Cooperative Solar Array. As a result of this test, changes were made to improve aspects of the solar cell coupon-to-support frame interface. It is unfortunate that the test's validity was somewhat compromised due to deviations in the test articles and the initial difficulties with the test facility. However, most of the physical changes and the electrical degradation at elevated temperatures was most likely due only to these initial problems, not related to thermal cycling. Since there was no significant degradation in the structural integrity of the test articles and no electrical degradation (not including the one cell damaged early and removed from consideration), it can reasonably be concluded from the results of this test that the integration of the US PPMs with the Russian support structure will be able to withstand at least 24000 thermal cycles ( 4 years on-orbit).

\section{REFERENCES}

Chau, M. T. and Brisco, H. N., 1995, "Elevated Temperature Testing of Mir 1 Cooperative Solar Array Photovoltaic Panel Module," IECEC paper no. AP-206, p. 357-362.

Hoffman, D.J. and Scheiman, D. A., 1996, "Mir Cooperative Solar Array Project Accelerated Life Thermal Cycling Test", NASA Technical Memorandum 107197.

Scheiman, D. A. and Smith, B. K., 1992, "Rapid Thermal Cycling of Solar Array Blanket Coupons for Space Station Freedom", Solar Engineering, Vol. 2 ASME, pp. 817-823. 



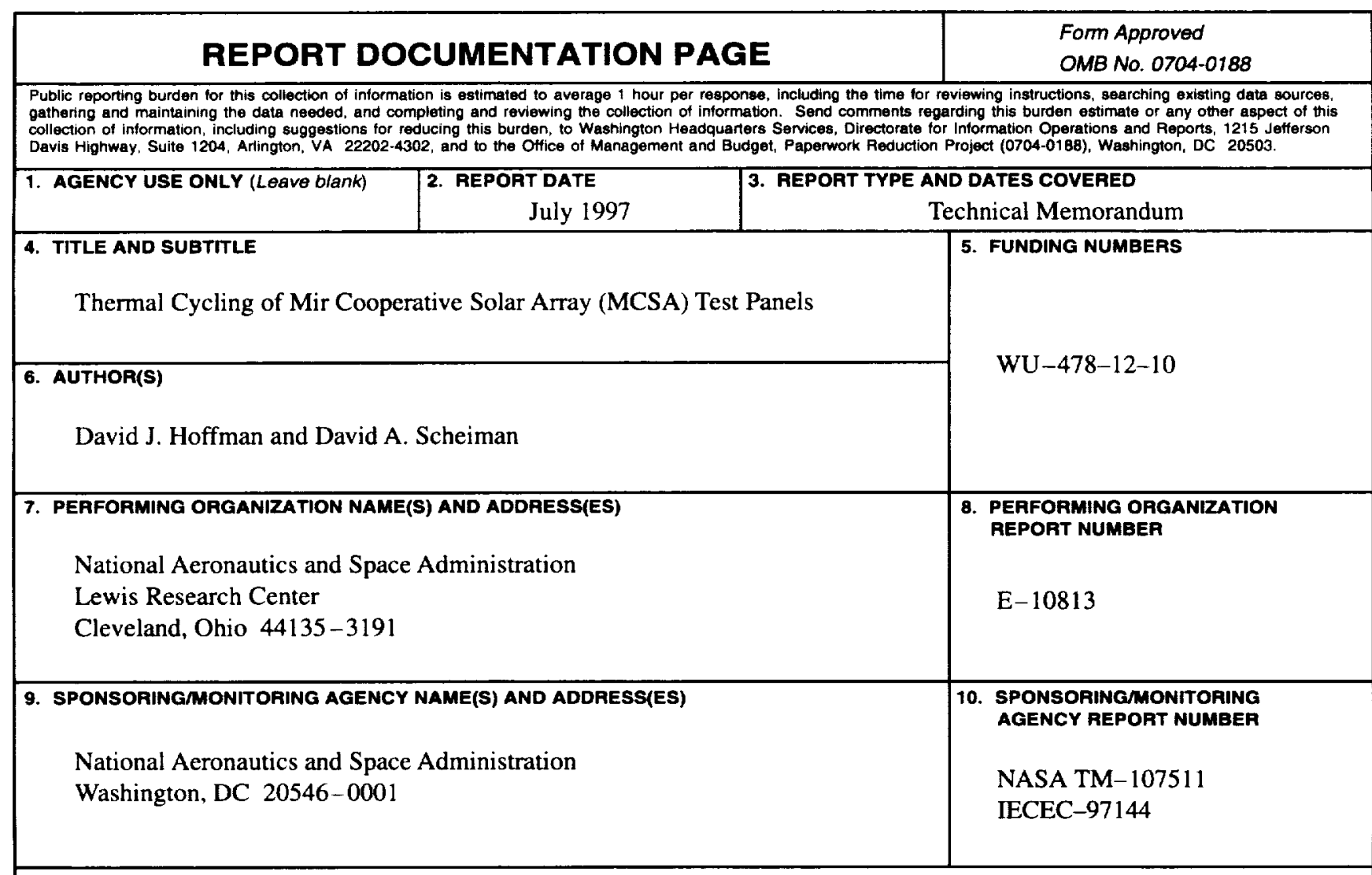

11. SUPPLEMENTARY NOTES

Prepared for the 32nd Intersociety Energy Conversion Engineering Conference cosponsored by AIChE, ANS, SAE, AIAA, ASME, and IEEE, Honolulu, Hawaii, July 27-August 1, 1997. David J. Hoffman, NASA Lewis Research Center, and David A. Scheiman, NYMA, Inc., 2001 Aerospace Parkway, Brook Park, Ohio 44135 (work performed under NASA Contract NAS3-27186). Responsible person, David J. Hoffman, organization code 6920, (216) 433-2445.

12a. DISTRIBUTION/AVAILABILITY STATEMENT 12b. DISTRIBUTION CODE

Unclassified - Unlimited

Subject Category 15,20

This publication is available from the NASA Center for AeroSpace Information, (301) 621-0390.

13. ABSTRACT (Maximum 200 words)

The Mir Cooperative Solar Array (MCSA) project was a joint US/Russian effort to build a photovoltaic (PV) solar array and deliver it to the Russian space station Mir. The MCSA is currently being used to increase the electrical power on Mir and provide PV array performance data in support of Phase I of the International Space Station (ISS), which will use arrays based on the same solar cells used in the MCSA. The US supplied the photovoltaic power modules (PPMs) and provided technical and programmatic oversight while Russia provided the array support structures and deployment mechanism and built and tested the array. In order to ensure that there would be no problems with the interface between US and Russian hardware, an accelerated thermal life cycle test was performed at NASA Lewis Research Center on two representative samples of the MCSA. Over an eight-month period (August 1994-March 1995), two 15-cell MCSA solar array "mini" panel test articles were simultaneously put through 24000 thermal cycles $\left(+80^{\circ} \mathrm{C}\right.$ to $\left.-100^{\circ} \mathrm{C}\right)$, equivalent to four years on-orbit. The test objectives, facility, procedure and results are described in this paper. Post-test inspection and evaluation revealed no significant degradation in the structural integrity of the test articles and no electrical degradation, not including one cell damaged early as an artifact of the test and removed from consideration. The interesting nature of the performance degradation caused by this one cell, which only occurred at elevated temperatures, is discussed. As a result of this test, changes were made to improve some aspects of the solar cell coupon-to-support frame interface on the flight unit. It was concluded from the results that the integration of the US solar cell modules with the Russian support structure would be able to withstand at least 24000 thermal cycles (4 years on-orbit).

\section{SUBJECT TERMS}

Thermal cycling; Photovoltaic; Solar array; Mir Space Station

\begin{tabular}{|c|c|}
\hline $\begin{array}{c}\text { 17. SECURITY CLASSIFICATION } \\
\text { OF REPOAT } \\
\text { Unclassified }\end{array}$ & $\begin{array}{c}\text { 18. SECURITY CLASSIFICATION } \\
\text { OF THIS PAGE } \\
\text { Unclassified }\end{array}$ \\
\hline
\end{tabular}

NSN 7540-01-280-5500

19. SECURITY CLASSIFICATION
OF ABSTRACT
Unclassified

\begin{tabular}{l} 
15. NUMBER OF PAGES \\
8 \\
\hline $\begin{array}{c}\text { 16. PAICE CODE } \\
\text { A02 }\end{array}$ \\
\hline $\begin{array}{l}\text { 20. LIMITATION OF ABSTRACT } \\
\text { Standard Form 298 (Rev. 2-89) } \\
\text { Prescribed by ANSI Std. Z39-18 } \\
298-102\end{array}$
\end{tabular}

